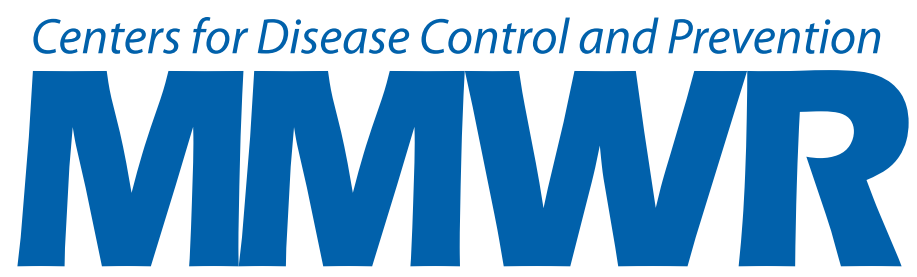

Morbidity and Mortality Weekly Report

Weekly / Vol. 62 / No. 25

June 28, 2013

\title{
West Nile Virus and Other Arboviral Diseases — United States, 2012
}

Arthropod-borne viruses (arboviruses) are transmitted to humans primarily through the bites of infected mosquitoes and ticks. West Nile virus (WNV) is the leading cause of domestically acquired arboviral disease in the United States (1). However, several other arboviruses also cause sporadic cases and seasonal outbreaks of neuroinvasive disease (e.g., meningitis, encephalitis, and acute flaccid paralysis) (1). In 2012, CDC received reports of 5,780 nationally notifiable arboviral disease cases (excluding dengue). A large multistate outbreak of WNV disease accounted for 5,674 (98\%) of reported cases, the highest number reported since 2003. Other reported etiologies included Eastern equine encephalitis virus (EEEV), Powassan virus (POWV), St. Louis encephalitis virus (SLEV), and California serogroup viruses such as La Crosse virus (LACV) and Jamestown Canyon virus (JCV). Arboviruses continue to cause serious illness in substantial numbers of persons in the United States. Maintaining surveillance remains important to identify outbreaks and guide prevention efforts.

In the United States, most arboviruses are maintained in transmission cycles between arthropods and vertebrate hosts (typically birds or small mammals). Humans usually become infected when bitten by infected mosquitoes or ticks. Person-to-person transmission occurs rarely through blood transfusion and organ transplantation. The majority of human arboviral infections are asymptomatic. Symptomatic infections most often manifest as a systemic febrile illness and, less commonly, as neuroinvasive disease. Most endemic arboviral diseases are nationally notifiable and are reported to CDC through ArboNET (2,3). In addition to collecting data on human disease cases, ArboNET collects data on viremic blood donors, veterinary disease cases, and infections in mosquitoes, dead birds, and sentinel chickens. Using standard definitions, human cases with laboratory evidence of recent arboviral infection are classified as neuroinvasive disease or nonneuroinvasive disease (2). Because of the substantial associated morbidity, detection and reporting of neuroinvasive disease cases is assumed to be more consistent and complete than for nonneuroinvasive disease cases. Therefore, incidence rate calculations were limited to neuroinvasive disease cases.
In 2012, CDC received reports of 5,780 cases of nationally notifiable arboviral diseases, including those caused by WNV (5,674 cases), LACV (78), EEEV (15), POWV (seven), SLEV (three), JCV (two), and an unspecified California serogroup virus (one). Cases were reported from 1,020 (32\%) of the 3,141 U.S. counties; no cases were reported from Alaska or Hawaii. Of the 5,780 total cases, 2,969 (51\%) were reported as neuroinvasive disease, for a national incidence of 0.95 per 100,000 population.

A total of 5,674 WNV disease cases, including 2,873 (51\%) neuroinvasive cases, were reported from 976 counties in 48 states, the District of Columbia, and Puerto Rico (Table 1). WNV disease cases peaked in late August, with 5,199 (92\%) cases having illness onset during July-September. The median age of patients was 56 years (interquartile range [IQR]: 42-68 years); 3,193 (56\%) were male. Overall, 3,491 (62\%) patients were hospitalized, and $286(5 \%)$ died. The median age of patients who died was 77 years (IQR: 68-84 years).

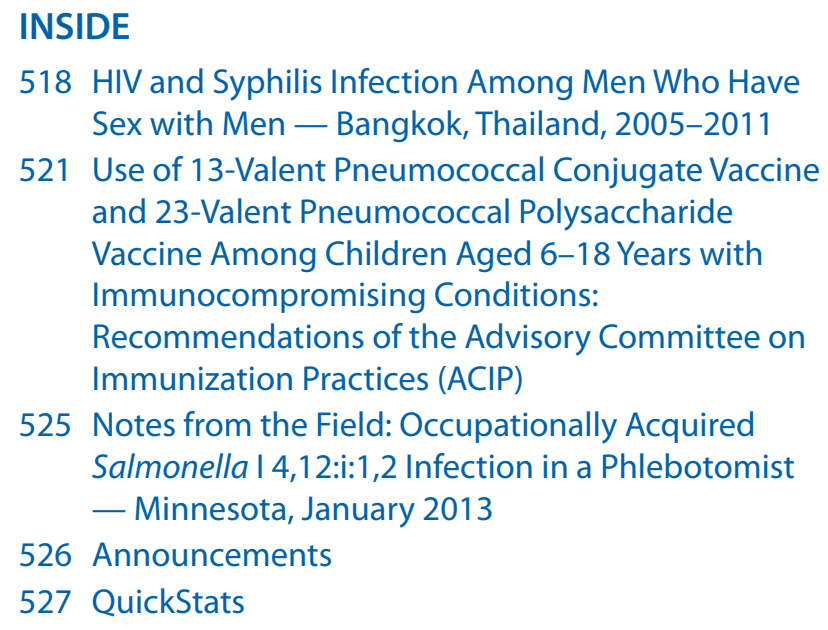
Sex with Men - Bangkok, Thailand, 2005-2011

521 Use of 13-Valent Pneumococcal Conjugate Vaccine and 23-Valent Pneumococcal Polysaccharide Vaccine Among Children Aged 6-18 Years with Immunocompromising Conditions: Recommendations of the Advisory Committee on Immunization Practices (ACIP)

525 Notes from the Field: Occupationally Acquired Salmonella | 4,12:i:1,2 Infection in a Phlebotomist - Minnesota, January 2013

526 Announcements

527 QuickStats

Continuing Education examination available at http://www.cdc.gov/mmwr/cme/conted_info.html\#weekly.

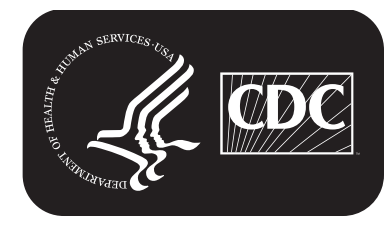

U.S. Department of Health and Human Services Centers for Disease Control and Prevention 
TABLE 1. Number and percentage of reported cases of arboviral disease, by virus and selected characteristics — United States, 2012*

\begin{tabular}{|c|c|c|c|c|c|c|c|c|}
\hline \multirow[b]{3}{*}{ Characteristic } & \multicolumn{8}{|c|}{ Virus } \\
\hline & \multicolumn{2}{|c|}{$\begin{array}{l}\text { West Nile } \\
(N=5,674)\end{array}$} & \multicolumn{2}{|c|}{$\begin{array}{l}\text { La Crosse } \\
(\mathrm{N}=78)\end{array}$} & \multicolumn{2}{|c|}{$\begin{array}{l}\text { Eastern equine encephalitis } \\
\qquad(\mathrm{N}=15)\end{array}$} & \multicolumn{2}{|c|}{$\begin{array}{c}\text { Powassan } \\
(\mathrm{N}=7)\end{array}$} \\
\hline & No. & (\%) & No. & (\%) & No. & (\%) & No. & (\%) \\
\hline \multicolumn{9}{|l|}{ Age group (yrs) } \\
\hline$<18$ & 210 & (4) & 65 & $(83)$ & 4 & (27) & 0 & - \\
\hline $18-59$ & 3,124 & (55) & 11 & (14) & 4 & (27) & 4 & (57) \\
\hline$\geq 60$ & 2,340 & (41) & 2 & (3) & 7 & (47) & 3 & (43) \\
\hline \multicolumn{9}{|l|}{ Sex } \\
\hline Male & 3,193 & (56) & 44 & (56) & 13 & (87) & 4 & (57) \\
\hline Female & 2,481 & (44) & 34 & (44) & 2 & (13) & 3 & (43) \\
\hline \multicolumn{9}{|l|}{ Period of illness onset } \\
\hline January-March & 2 & $(<1)$ & 1 & (1) & 0 & - & 0 & - \\
\hline April-June & 130 & (2) & 13 & (17) & 1 & (7) & 7 & $(100)$ \\
\hline July-September & 5,199 & $(92)$ & 59 & (76) & 13 & (87) & 0 & - \\
\hline October-December & 343 & (6) & 5 & (6) & 1 & (7) & 0 & - \\
\hline \multicolumn{9}{|l|}{ Clinical syndrome } \\
\hline Nonneuroinvasive & 2,801 & (49) & 7 & (9) & 0 & - & 0 & - \\
\hline Neuroinvasive & 2,873 & (51) & 71 & (91) & 15 & $(100)$ & 7 & $(100)$ \\
\hline Encephalitis & 1,615 & $(28)$ & 56 & (72) & 13 & $(87)$ & 4 & (57) \\
\hline Meningitis & 1,038 & $(18)$ & 14 & $(18)$ & 2 & (13) & 3 & (43) \\
\hline Acute flaccid paralysis ${ }^{\dagger}$ & 220 & (4) & 1 & (1) & 0 & - & 0 & - \\
\hline \multicolumn{9}{|l|}{ Outcome } \\
\hline Hospitalization & 3,491 & $(62)$ & 76 & (97) & 14 & (93) & 6 & $(86)$ \\
\hline Death & 286 & (5) & 1 & (1) & 5 & (33) & 0 & - \\
\hline
\end{tabular}

* Three California serogroup virus disease cases in addition to the La Crosse virus disease cases were reported, including two caused by Jamestown Canyon virus and one unspecified.

† Of the 220 West Nile virus disease patients with acute flaccid paralysis, $183(83 \%)$ also had encephalitis or meningitis. The La Crosse virus disease patient with acute flaccid paralysis also had encephalitis.

Of the 2,873 WNV neuroinvasive disease patients, 1,615 (56\%) had encephalitis, $1,038(36 \%)$ had meningitis, and $220(8 \%)$ had acute flaccid paralysis. Among the 220 patients with acute flaccid paralysis, $183(83 \%)$ also had encephalitis or meningitis. The national incidence of neuroinvasive WNV disease was 0.92 per 100,000 population (Table 2). States with the highest incidence rates included South Dakota (7.44 per 100,000), North Dakota (5.57), Mississippi (3.45), Louisiana

The $M M W R$ series of publications is published by the Office of Surveillance, Epidemiology, and Laboratory Services, Centers for Disease Control and Prevention (CDC), U.S. Department of Health and Human Services, Atlanta, GA 30333.

Suggested citation: Centers for Disease Control and Prevention. [Article title]. MMWR 2013;62:[inclusive page numbers].

\section{Centers for Disease Control and Prevention \\ Thomas R. Frieden, MD, MPH, Director \\ Harold W. Jaffe, MD, MA, Associate Director for Science \\ James W. Stephens, PhD, Director, Office of Science Quality}

Denise M. Cardo, MD, Acting Deputy Director for Surveillance, Epidemiology, and Laboratory Services Stephanie Zaza, MD, MPH, Director, Epidemiology and Analysis Program Office

MMWR Editorial and Production Staff

Ronald L. Moolenaar, MD, MPH, Editor, MMWR Series

John S. Moran, MD, MPH, Deputy Editor, MMWR Series

Teresa F. Rutledge, Managing Editor, MMWR Series

Douglas W. Weatherwax, Lead Technical Writer-Editor

Donald G. Meadows, MA, Jude C. Rutledge, Writer-Editors

Martha F. Boyd, Lead Visual Information Specialist

MMWR Editorial Board

William L. Roper, MD, MPH, Chapel Hill, NC, Chairman

Matthew L. Boulton, MD, MPH, Ann Arbor, MI

Virginia A. Caine, MD, Indianapolis, IN

Barbara A. Ellis, PhD, MS, Atlanta, GA

Jonathan E. Fielding, MD, MPH, MBA, Los Angeles, CA David W. Fleming, MD, Seattle, WA

William E. Halperin, MD, DrPH, MPH, Newark, NJ King K. Holmes, MD, PhD, Seattle, WA
Maureen A. Leahy, Julia C. Martinroe, Stephen R. Spriggs, Terraye M. Starr Visual Information Specialists Quang M. Doan, MBA, Phyllis H. King Information Technology Specialists

Timothy F. Jones, MD, Nashville, TN

Rima F. Khabbaz, MD, Atlanta, GA

Dennis G. Maki, MD, Madison, WI

Patricia Quinlisk, MD, MPH, Des Moines, IA

Patrick L. Remington, MD, MPH, Madison, WI

John V. Rullan, MD, MPH, San Juan, PR William Schaffner, MD, Nashville, TN 
(3.37), and Texas (3.24) (Figure). Four states reported over half of the WNV neuroinvasive disease cases: Texas (844 cases), California (297), Illinois (187), and Louisiana (155). Neuroinvasive WNV disease incidence increased with age, with the highest incidence among persons aged $\geq 70$ years. Among patients with neuroinvasive disease, 270 (9\%) died.

The $78 \mathrm{LACV}$ disease cases were reported from 50 counties in 11 states; 71 (91\%) were neuroinvasive (Table 1). Dates of illness onset for LACV disease cases ranged from March through October; 13 (17\%) had onset during April-June, and $59(76 \%)$ had illness onset during July-September. Forty-four (56\%) patients were male. The median age of patients was 9 years (IQR: 6-13 years); 65 (83\%) were aged $<18$ years. LACV neuroinvasive disease incidence was highest in West Virginia (0.49 per 100,000), North Carolina (0.27), Tennessee (0.14), and Ohio (0.10) (Table 2). Those four states reported 56 (79\%) LACV neuroinvasive disease cases. A total of 76 (97\%) patients were hospitalized; one (1\%) died. Three California serogroup virus disease cases in addition to the LACV cases were reported, including two caused by JCV and one unspecified.
FIGURE. Rate* of reported cases of West Nile virus neuroinvasive disease, by state — United States, 2012

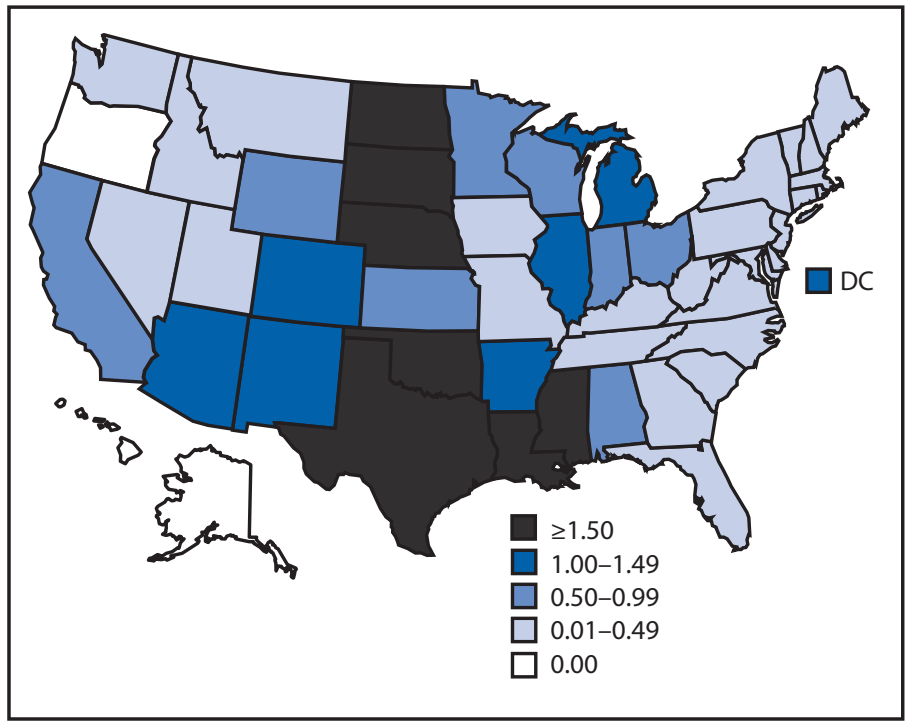

* Per 100,000 population, based on July 1, 2012 U.S. Census population estimates.

TABLE 2. Number and rate* of reported cases of arboviral neuroinvasive disease, by virus, U.S. Census region, and state - United States, 2012

\begin{tabular}{|c|c|c|c|c|c|c|c|c|}
\hline \multirow[b]{3}{*}{ U.S. Census region and state } & \multicolumn{8}{|c|}{ Virus } \\
\hline & \multicolumn{2}{|c|}{ West Nile } & \multicolumn{2}{|c|}{ La Crosse } & \multicolumn{2}{|c|}{ Eastern equine encephalitis } & \multicolumn{2}{|c|}{ Powassan } \\
\hline & No. & Rate & No. & Rate & No. & Rate & No. & Rate \\
\hline United States & 2,873 & 0.92 & 71 & 0.02 & 15 & $<0.01$ & 7 & $<0.01$ \\
\hline New England & 42 & 0.29 & - & - & 9 & 0.06 & - & - \\
\hline Connecticut & 12 & 0.33 & - & - & - & - & - & - \\
\hline Maine & 1 & 0.08 & - & - & - & - & - & - \\
\hline Massachusetts & 25 & 0.38 & - & - & 7 & 0.11 & - & 一 \\
\hline New Hampshire & 1 & 0.08 & - & - & - & - & - & 一 \\
\hline Rhode Island & 2 & 0.19 & - & - & - & - & - & - \\
\hline Vermont & 1 & 0.16 & - & - & 2 & 0.32 & - & - \\
\hline Middle Atlantic & 116 & 0.28 & - & - & - & - & 1 & $<0.01$ \\
\hline New Jersey & 22 & 0.25 & - & - & - & - & - & - \\
\hline New York & 61 & 0.31 & - & - & - & - & 1 & 0.01 \\
\hline Pennsylvania & 33 & 0.26 & - & - & - & - & - & - \\
\hline East North Central & 494 & 1.06 & 16 & 0.03 & - & - & 2 & $<0.01$ \\
\hline Illinois & 187 & 1.45 & - & - & - & - & - & - \\
\hline Indiana & 46 & 0.70 & 2 & 0.03 & - & - & - & 一 \\
\hline Michigan & 141 & 1.43 & - & - & - & - & - & - \\
\hline Ohio & 76 & 0.66 & 12 & 0.10 & - & - & - & - \\
\hline Wisconsin & 44 & 0.77 & 2 & 0.03 & - & - & 2 & 0.03 \\
\hline West North Central & 225 & 1.08 & 4 & 0.02 & - & - & 4 & 0.02 \\
\hline lowa & 11 & 0.36 & - & - & - & - & - & 一 \\
\hline Kansas & 20 & 0.69 & - & - & - & - & - & - \\
\hline Minnesota & 34 & 0.63 & 4 & 0.07 & - & - & 4 & 0.07 \\
\hline Missouri & 17 & 0.28 & - & - & - & - & - & 一 \\
\hline Nebraska & 42 & 2.26 & - & - & - & - & - & - \\
\hline North Dakota & 39 & 5.57 & - & - & - & - & - & 一 \\
\hline South Dakota & 62 & 7.44 & - & - & - & - & - & - \\
\hline South Atlantic & 185 & 0.30 & 38 & 0.06 & 5 & $<0.01$ & - & 一 \\
\hline Delaware & 2 & 0.22 & - & - & - & - & - & - \\
\hline District of Columbia & 8 & 1.27 & - & - & - & - & - & 一 \\
\hline Florida & 52 & 0.27 & - & - & 2 & 0.01 & - & - \\
\hline Georgia & 46 & 0.46 & - & - & 1 & 0.01 & - & - \\
\hline Maryland & 25 & 0.42 & - & - & - & - & - & - \\
\hline
\end{tabular}

See table footnotes on the next page. 
Please note: Errata have been published for this issue. To view the errata, please click here and here.

Morbidity and Mortality Weekly Report

TABLE 2. (Continued) Number and rate* of reported cases of arboviral neuroinvasive disease, by virus, U.S. Census region, and state - United States, 2012

\begin{tabular}{|c|c|c|c|c|c|c|c|c|}
\hline \multirow[b]{3}{*}{ U.S. Census region and state } & \multicolumn{8}{|c|}{ Virus } \\
\hline & \multicolumn{2}{|c|}{ West Nile } & \multicolumn{2}{|c|}{ La Crosse } & \multicolumn{2}{|c|}{ Eastern equine encephalitis } & \multicolumn{2}{|c|}{ Powassan } \\
\hline & No. & Rate & No. & Rate & No. & Rate & No. & Rate \\
\hline North Carolina & 7 & 0.07 & 26 & 0.27 & 2 & 0.02 & - & - \\
\hline South Carolina & 20 & 0.42 & 1 & 0.02 & - & - & - & - \\
\hline Virginia & 20 & 0.24 & 2 & 0.02 & 1 & 0.01 & - & - \\
\hline West Virginia & 5 & 0.27 & 9 & 0.49 & - & - & - & - \\
\hline East South Central & 173 & 0.93 & 10 & 0.05 & - & - & - & - \\
\hline Alabama & 38 & 0.79 & - & - & - & - & - & - \\
\hline Kentucky & 13 & 0.30 & - & - & - & - & - & - \\
\hline Mississippi & 103 & 3.45 & 1 & 0.03 & - & - & - & - \\
\hline Tennessee & 19 & 0.29 & 9 & 0.14 & - & - & - & - \\
\hline West South Central & 1,146 & 3.08 & 3 & 0.01 & - & - & - & - \\
\hline Arkansas & 44 & 1.49 & - & - & - & - & - & - \\
\hline Louisiana & 155 & 3.37 & - & - & - & - & - & - \\
\hline Oklahoma & 103 & 2.70 & - & - & - & - & - & - \\
\hline Texas & 844 & 3.24 & 3 & 0.01 & - & - & - & - \\
\hline Mountain & 190 & 0.84 & - & - & - & - & - & - \\
\hline Arizona & 87 & 1.33 & - & - & - & - & - & - \\
\hline Colorado & 62 & 1.20 & - & - & - & - & - & - \\
\hline Idaho & 5 & 0.31 & - & - & - & - & - & - \\
\hline Montana & 1 & 0.10 & - & - & - & - & - & - \\
\hline Nevada & 5 & 0.18 & - & - & - & - & - & - \\
\hline New Mexico & 24 & 1.15 & - & - & - & - & - & - \\
\hline Utah & 3 & 0.11 & - & - & - & - & - & - \\
\hline Wyoming & 3 & 0.52 & - & - & - & - & - & - \\
\hline Pacific & 301 & 0.59 & - & - & - & - & - & - \\
\hline Alaska & - & - & - & - & - & - & - & - \\
\hline California & 297 & 0.78 & - & - & - & - & - & - \\
\hline Hawaii & - & - & - & - & - & - & - & - \\
\hline Oregon & - & - & - & - & - & - & - & - \\
\hline Washington & 4 & 0.06 & - & - & - & - & - & - \\
\hline \multicolumn{9}{|l|}{ Territories } \\
\hline Puerto Rico & 1 & 0.03 & - & - & - & - & - & - \\
\hline
\end{tabular}

* Per 100,000 population, based on July 1, 2012 U.S. Census population estimates.

Fifteen EEEV neuroinvasive disease cases were reported from six states: Massachusetts (seven cases), North Carolina (two), Vermont (two), Florida (two), Georgia (one), and Virginia (one) (Table 1). Dates of illness onset ranged from June through October, with 13 (87\%) occurring during July-September. The median age of patients was 57 years (IQR: 11-68 years); 13 (87\%) were male. Fourteen (93\%) patients were hospitalized; five $(33 \%)$ died. The median age of patients who died was 76 years (IQR: 63-79 years).

Seven POWV neuroinvasive disease cases were reported from three states: Minnesota (four cases), Wisconsin (two), and New York (one) (Table 1). Dates of illness onset for all cases were in May or June. All cases occurred in adult patients (median age: 58 years [IQR: 36-73 years]); four were male. Six (86\%) patients were hospitalized; none died.

Three SLEV disease cases were reported from Texas; only one was neuroinvasive. Dates of illness onset were in July and August. All cases occurred in adults aged 40-60 years. One of the three SLEV patients was hospitalized; none died.
Reported by

Nicole P. Lindsey, MS, Jennifer A. Lehman, J. Erin Staples, MD, Marc Fischer, MD, Div of Vector-Borne Diseases, National Center for Emerging and Zoonotic Infectious Diseases, CDC. Corresponding contributor: Nicole Lindsey,nplindsey@cdc.gov, 970-221-6400.

\section{Editorial Note}

A large multistate outbreak of WNV disease occurred in 2012, with more cases reported nationally than in any year since 2003, including the first reported human case from Maine. The 15 EEEV disease cases reported in 2012 were the most reported since 2005, and included the first cases ever reported from Vermont. EEEV disease remained the most severe domestic arboviral disease, with a 33\% case-fatality rate. Over $90 \%$ of arboviral disease cases occurred during July-September, and most of the remainder occurred during April-June, emphasizing the importance of focusing public health interventions on these periods. 
The national incidence of WNV neuroinvasive disease peaked in 2002 (1.02 per 100,000) and 2003 (0.98) (3). During 2004-2011, annual incidence was relatively low (median: 0.31; range: 0.13-0.50) (3-6). In 2012, the national incidence of WNV neuroinvasive disease increased to 0.92 per 100,000. The increase in disease was widespread, with 43 states reporting a higher incidence in 2012 compared with the median for 2004-2011; however, more than half of the neuroinvasive disease cases in 2012 were reported from just four states, and $29 \%$ were reported from Texas alone. Of the five states with a lower incidence in 2012 compared with the previous 8 years, four were in the Mountain Region (Montana, Nevada, Utah, and Wyoming). Oregon also reported lower rates compared with recent years; Alaska and Hawaii have never reported a case of WNV disease.

Reported numbers of arboviral disease cases vary from year to year. It is not clear why more WNV activity occurred this year than in recent years. The weather, numbers of birds that maintain the virus, numbers of mosquitoes that spread the virus, and human behavior are all factors that can influence when and where outbreaks occur. Because of this complex ecology, it is difficult to predict how many cases of disease might occur in the future and in what areas.

The findings in this report are subject to at least two limitations. First, ArboNET is a passive surveillance system that relies on clinicians to consider the diagnosis of an arboviral disease and obtain appropriate diagnostic test results and on healthcare providers and laboratories to report laboratory-confirmed cases to public health authorities. Second, testing and reporting are incomplete, leading to a substantial underestimate of the actual number of cases (7). Based on previous studies, for every reported case of WNV neuroinvasive disease, there are an estimated 30-70 nonneuroinvasive disease cases. Extrapolating from the 2,873 WNV neuroinvasive disease cases reported, an estimated 86,000-200,000 nonneuroinvasive disease cases might have occurred in 2012. However, only 2,801 (1\%-3\%) were diagnosed and reported.

Arboviruses continue to cause severe illness in substantial numbers of persons in the United States. However, cases occur sporadically, and the epidemiology varies by virus and geographic area. Surveillance is essential to identify outbreaks and guide prevention efforts aimed at reducing the incidence of these diseases. Health-care providers should consider arboviral infections in the differential diagnosis of cases of aseptic meningitis and encephalitis, obtain appropriate specimens for laboratory testing, and promptly report cases to public health authorities (2). Because human vaccines against domestic arboviruses are not available, prevention of arboviral disease depends on community and household efforts to reduce vector populations (e.g., applying insecticides and reducing mosquito
What is already known on this topic?

West Nile virus (WNV) is the leading cause of domestically acquired arboviral disease in the United States. However, several other arboviruses can cause sporadic cases and outbreaks of neuroinvasive disease, mainly in the summer.

What is added by this report?

A large multistate outbreak of WNV disease occurred in 2012. The 5,674 cases reported nationally were the highest number of cases reported since 2003. Eastern equine encephalitis, although rare, remained the most severe arboviral disease, with a $33 \%$ case-fatality rate.

What are the implications for public health practice?

WNV and other arboviruses continue to be a source of severe illness each year for substantial numbers of persons in the United States. Maintaining surveillance remains important to identify outbreaks and guide prevention efforts.

breeding sites), personal protective measures to decrease exposure to mosquitoes and ticks (e.g., use of repellents and wearing protective clothing), and screening blood donors. Updated guidelines for WNV surveillance, prevention, and control are available online from CDC at http://www.cdc.gov/westnile/ resources/pdfs/wnvguidelines.pdf.

\section{Acknowledgments}

ArboNET surveillance coordinators in state and local health departments. Ned Hayes, MD, Div of Vector-Borne Diseases, CDC.

\section{References}

1. Reimann CA, Hayes EB, DiGuiseppi C, et al. Epidemiology of neuroinvasive arboviral disease in the United States, 1999-2007. Am J Trop Med Hyg 2008;79:974-9.

2. CDC. Arboviral diseases, neuroinvasive and non-neuroinvasive: 2011 case definition. Atlanta, GA: US Department of Health and Human Services, CDC; 2011. Available at http://wwwn.cdc.gov/nndss/script/ casedef.aspx? condyrid=616\&datepub=1/1/2011 12:00:00 am.

3. CDC. Surveillance for human West Nile virus disease-United States, 1999-2008. MMWR 2010;59(No. SS-2).

4. CDC. West Nile virus activity-United States, 2009. MMWR 2010; 59:769-72.

5. CDC. West Nile virus disease and other arboviral diseases-United States, 2010. MMWR 2011;60:1009-13.

6. CDC. West Nile virus disease and other arboviral diseases-United States, 2011. MMWR 2012;61:510-4.

7. Weber IB, Lindsey NP, Bunko-Patterson AM, et al. Completeness of West Nile virus testing in patients with meningitis and encephalitis during an outbreak in Arizona, USA. Epidemiol Infect 2012;140:1632-6.

8. Mostashari F, Bunning ML, Kitsutani PT, et al. Epidemic West Nile encephalitis, New York, 1999: results of a household-based seroepidemiological survey. Lancet 2001;358:261-4.

9. Busch MP, Wright DJ, Custer B, et al. West Nile virus infections projected from blood donor screening data, United States, 2003. Emerg Infect Dis 2006;12:395-402.

10. Carson PJ, Borchardt SM, Custer B, et al. Neuroinvasive disease and West Nile virus infection, North Dakota, USA, 1999-2008. Emerg Infect Dis 2012;18:684-6. 


\section{HIV and Syphilis Infection Among Men Who Have Sex with Men - Bangkok, Thailand, 2005-2011}

Although efforts to control the heterosexual human immunodeficiency virus (HIV) epidemic in Thailand had shown success by the late 1990s (1), HIV continued to spread in other risk groups, including men who have sex with men (MSM). In 2003, the Thailand Ministry of Public Health-U.S. CDC Collaboration (TUC) started surveillance among MSM in Bangkok, finding an HIV prevalence of $17.3 \%$ (2). By 2005, HIV prevalence in this group had risen to $28.3 \%$ and has since stabilized at around $30 \%(2,3)$. To obtain additional information about HIV and sexually transmitted infection (STI) prevalence and incidence in a clinic-based population of MSM, TUC, in collaboration with the Thai Red Cross AIDS Research Center, analyzed data collected at the Silom Community Clinic (SCC), an HIV and STI testing center targeting MSM. This report describes trends in HIV and syphilis prevalence and incidence seen among SCC MSM clients during 2005-2011. At first clinic visit, the prevalence of HIV infection among 4,762 clients was $28.3 \%$ and of syphilis (all stages) was $9.8 \%$. Among those returning for HIV or syphilis testing before the end of 2011, the incidence of HIV infection was 6.3 per 100 person-years (PY) and 3.6 per $100 \mathrm{PY}$ for syphilis. These results show ongoing epidemics of HIV and syphilis infection in MSM in Bangkok, underscoring the urgent need for preventive interventions to reduce the spread of HIV and STI in this population.

The SCC is located in a central Bangkok hospital close to a large number of MSM entertainment venues and was founded by TUC in 2005. It supports an environment and staff receptive to the health and concerns of the MSM community; HIV and STI testing services are free, rapid, anonymous, and confidential. The long-term goal of the SCC is to build a durable relationship with the MSM community and to identify safe, effective, and affordable HIV prevention methods for MSM.

At first visit, all SCC attendees are offered HIV voluntary counseling and testing* and evaluation for primary, secondary, and latent syphilis. ${ }^{\dagger}$ Other procedures offered include testing for immunity to hepatitis $A$ and $B, \mathbb{S}$ hepatitis $B$ vaccination

\footnotetext{
*Alere Determine HIV 1/2 (Alere Medical Co., Ltd., Chiba, Japan), Double Check II HIV $1 \& 2$ (Orgenics Ltd., Yavne, Israel) (after February 2011 replaced by SD Bioline HIV-1/2 3.0 [Standard Diagnostics Inc., Kyonggi-do, Republic of Korea]), and Capillus HIV-1/HIV-2 (Trinity Biotech PLC, Bray, Ireland) (after November 2008 replaced by Core HIV-1\&2 [Core Diagnostics, Birmingham, United Kingdom]).

${ }^{\dagger}$ Rapid plasma reagin test, confirmed by immunochromatography (Alere Determine Syphilis TP, Alere Medical Co., Ltd., Chiba, Japan).

$\$$ Antibody against hepatitis A virus by enzyme-linked immunoassay (Murex anti-HAV [total]) and antibody against hepatitis B virus surface antigen (Murex anti-HBs, Murex Biotech Ltd., Dartford, United Kingdom).
}

(if eligible), and evaluation for the presence of gonococcal and nongonococcal urethral, pharyngeal, or rectal infections; genital ulcers; and warts. All testing, vaccination, and STI treatments are provided free of charge. Since July 2009, HIVnegative clients have been offered nucleic-acid amplification testing for acute HIV infection. Reactive nucleic-acid amplification testing in HIV antibody-negative persons is evidence of acute HIV infection, a phase of infection during which viral replication and infectiousness are high (4). All HIV-positive SCC attendees are offered a CD4+ T lymphocyte count 9 assess their eligibility for antiretroviral therapy (ART)** and antimicrobial treatment. Thailand offers free public health care to all its citizens, and HIV ART was included in 2006 (5). HIV and syphilis prevalence were calculated at the first SCC visit during 2005-2011 when this testing was performed. HIV and syphilis incidence were computed among those who tested negative for HIV or syphilis at first visit, who returned for testing later. Times between the date of the first negative test and the midpoint between the dates of the last negative and first positive HIV or syphilis test were used to calculate PY of follow-up time. Trends in HIV prevalence and incidence were evaluated for statistical significance using chi-square and Poisson exact tests.

During the 2005-2011 period, 4,762 MSM clients made a total of 15,219 visits to the SCC (Table). Most (60.9\%) clients were aged $<30$ years, $90.8 \%$ were Thai, $7.2 \%$ were non-Asian, and 2.0\% were other Asian. Almost all (91.8\%) resided in the Bangkok metropolitan area. Less than half $(42.7 \%)$ reported a history of previous HIV testing. The yearly number of clients increased from 221 in 2005 to 1,135 in 2011, and the yearly number of visits increased from 439 to 4,220 during the same period. Prevalence of HIV at first visit during 2005-2011 was $28.3 \%$ and of syphilis $9.8 \%$. HIV incidence was 6.3 per $100 \mathrm{PY}$ and of syphilis was 3.6 per 100 PY of follow-up. Of the 2,736 HIV-negative specimens evaluated by nucleic-acid amplification testing since July 2009, 15 tested positive for acute HIV infection (prevalence: $0.55 \%$ ). Among the 1,243 who tested HIV-positive, $41.9 \%$ had a CD $4+$ count of $\leq 350$ cells/ $\mu \mathrm{L}$, $29.1 \%$ had a count of $>350$ and $\leq 500$ cells $/ \mu \mathrm{L}$, and $29.0 \%$ had a count of $>500$ cells $/ \mu \mathrm{L}$. Although HIV prevalence was significantly higher among older attendees $(29.5 \%$ among those aged $\geq 30$ years versus $22.8 \%$ for those aged $\leq 21$ years), HIV incidence was significantly higher in the younger age

\footnotetext{
$\checkmark$ EasyCD4 System (Guava Technologies Inc., Hayward, California). ** Currently $\leq 350$ cells $\mu \mathrm{L}$ in Thailand.
} 
Please note: An erratum has been published for this issue. To view the erratum, please click here.

Morbidity and Mortality Weekly Report

TABLE. HIV and syphilis prevalence and incidence among men who have sex with men, by age group and calendar year — Silom Community Clinic, Bangkok, Thailand, 2005-2011

\begin{tabular}{|c|c|c|c|c|c|c|c|c|c|c|c|c|}
\hline \multirow[b]{3}{*}{ Characteristic } & \multirow{2}{*}{\multicolumn{2}{|c|}{ Clients }} & \multirow{2}{*}{\multicolumn{2}{|c|}{ Visits }} & \multicolumn{4}{|c|}{ Prevalence } & \multicolumn{4}{|c|}{ Incidence } \\
\hline & & & & & \multicolumn{2}{|l|}{ HIV } & \multicolumn{2}{|c|}{ Syphilis* } & \multicolumn{2}{|c|}{ HIV } & \multicolumn{2}{|c|}{ Syphilis* } \\
\hline & No. & $(\%)$ & No. & (\%) & Proportion & (\%) & Proportion & (\%) & Rate & (per 100 PY) & Rate & (per $100 \mathrm{PY}$ ) \\
\hline Totals & 4,762 & $(100)$ & 15,219 & $(100)$ & $1,243 / 4,398$ & (28.3) & $424 / 4,324$ & $(9.8)$ & $109 / 1,733$ & $(6.3)$ & $75 / 2,106$ & $(3.6)$ \\
\hline \multicolumn{13}{|l|}{ Age group (yrs) ${ }^{\dagger}$} \\
\hline $15-21$ & 662 & (13.9) & 2,222 & (14.6) & $148 / 650$ & $(22.8)$ & $66 / 635$ & (10.4) & $25 / 205$ & $(12.2)$ & $10 / 242$ & $(4.1)$ \\
\hline $22-29$ & 2,238 & $(47.0)$ & 7,046 & $(46.3)$ & $603 / 2,078$ & (29.0) & $182 / 2,041$ & $(8.9)$ & $61 / 798$ & (7.6) & $40 / 1,003$ & $(4.0)$ \\
\hline$\geq 30$ & 1,862 & (39.1) & 5,951 & (39.1) & $492 / 1,670$ & (29.5) & $176 / 1,648$ & (10.7) & 23/730 & $(3.2)$ & $25 / 861$ & $(2.9)$ \\
\hline Median (range) & 7 & $(14-80)$ & & - & 28 & $(17-80)$ & 28 & $(15-73)$ & 25 & $(16-76)$ & 28 & $(20-57)$ \\
\hline P-value ${ }^{\S}$ & & - & & - & 0.00 & & 0.4 & & & .001 & & 0.2 \\
\hline \multicolumn{13}{|l|}{ Calendar year } \\
\hline 2005 & 221 & $(4.6)$ & 439 & $(2.9)$ & $51 / 207$ & $(24.6)$ & $10 / 200$ & $(5.0)$ & $0 / 30$ & $(0.0)$ & $0 / 61$ & $(0.0)$ \\
\hline 2006 & 554 & (11.6) & 1,509 & (9.9) & $118 / 514$ & (23.0) & $16 / 505$ & $(3.2)$ & $5 / 147$ & (3.4) & $0 / 253$ & $(0.0)$ \\
\hline 2007 & 506 & (10.6) & 1,332 & (8.7) & $114 / 451$ & (25.3) & $27 / 440$ & (6.1) & $8 / 221$ & (3.6) & 3/191 & $(1.6)$ \\
\hline 2008 & 653 & (13.7) & 1,842 & (12.1) & $162 / 609$ & (26.6) & $27 / 611$ & (4.4) & $14 / 284$ & (4.9) & $1 / 312$ & $(0.3)$ \\
\hline 2009 & 748 & (15.7) & 2,582 & (17.0) & $191 / 696$ & (27.4) & 63/707 & (8.9) & $28 / 375$ & (7.5) & $19 / 467$ & $(4.1)$ \\
\hline 2010 & 945 & (19.8) & 3,295 & $(21.7)$ & $306 / 898$ & (34.1) & $157 / 867$ & (18.1) & $31 / 384$ & $(8.1)$ & $30 / 510$ & (5.9) \\
\hline 2011 & 1,135 & $(23.8)$ & 4,220 & $(27.7)$ & $301 / 1,023$ & (29.4) & $124 / 994$ & (12.5) & $23 / 292$ & (7.9) & $22 / 312$ & $(7.1)$ \\
\hline P-value ${ }^{\S}$ & \multicolumn{2}{|c|}{$<0.001$} & \multicolumn{2}{|c|}{$<0.001$} & \multicolumn{2}{|c|}{$<0.001$} & \multicolumn{2}{|c|}{$<0.001$} & \multicolumn{2}{|c|}{$<0.002$} & \multicolumn{2}{|c|}{$<0.001$} \\
\hline
\end{tabular}

Abbreviations: $\mathrm{HIV}=$ human immunodeficiency virus; $\mathrm{PY}=$ person years.

* Includes primary, secondary, and latent syphilis.

† Age at time of prevalent (first test) and incident (subsequent test) infection.

$\S$ Poisson exact test was used to evaluate trends in HIV and syphilis incidence; chi-square test for trend was used elsewhere.

group (12.2 per 100 PY for those aged $\leq 21$ years versus 3.2 per 100 PY for those aged $\geq 30$ years) (Table). From 2005 to 2011, significant increases occurred in the annual prevalence of HIV (from $24.6 \%$ to $29.4 \%$ ) and syphilis (from $5.0 \%$ to $12.5 \%)$. The incidence of HIV also increased significantly from 2005-2006 to 2011, from 2.8 per 100 PY to 7.9 per 100 PY, as did the incidence of syphilis, from 0.0 per $100 \mathrm{PY}$ to 7.1 per 100 PY (Table).

\section{Reported by}

Jintanat Ananworanich, $M D, P h D$, South East Asia Research Collaboration with Hawaii (SEARCH) Thailand, Thai Red Cross AIDS Research Center, Bangkok; Anupong Chitwarakorn, MD, Dept of Disease Control, Ministry of Public Health, Nonthaburi; Wipas Wimonsate, MSc, Anchalee Varangrat, MSc, Supaporn Chaikummao, Anuwat Sriporn, MSc, Jaray Tongtoyai, MSc, Philip Mock, MAppStat, Wichuda Sukwicha, Wannee Chonwattana, Pikunchai Luechai, Marcel Curlin, MD, Janet McNicholl, MD, Timothy Holtz, MD, Frits van Griensven, PhD, Thailand Ministry of Public Health-U.S. CDC Collaboration, Nonthaburi, Thailand. Corresponding contributors: Frits van Griensven, fritsvg@trcarc.org, +66-90-092-2908; Wipas Wimonsate,wipasw@th.cdc.gov,+66-81-641-6064.

\section{Editorial Note}

These data show ongoing and increasing epidemics of HIV and syphilis infection among MSM in Bangkok. While reemerging and increasing HIV and syphilis epidemics have been reported among MSM in industrialized countries ( 6 ), these data provide evidence for the existence of similar trends among MSM in a less developed country. Of particular concern are the higher HIV incidence (12.2 per 100 PY) found in MSM aged 15-21 years and the uniform syphilis incidence (3.6 per $100 \mathrm{PY}$ ) across all age categories.

At the first visit to the SCC, less than half of all clients reported a previous HIV test. Knowledge of HIV status has been shown to be associated with increased preventive behavior, particularly among those testing HIV-positive (7). In addition, knowledge of HIV status is necessary for linkage to care, treatment, and prevention services, including timely access to ART. A recent clinical trial of daily oral ART preexposure prophylaxis to prevent HIV infection in MSM demonstrated a $44 \%$ reduction in new HIV infections (8). In a trial of early ART of the HIV-infected partner in serodiscordant heterosexual couples, HIV transmission to the uninfected partner decreased by $96 \%$ (9). In the context of these recent advances in HIV prevention, increased HIV testing and linkage to ART in clinic-based settings such as the SCC might play an important role in reducing HIV transmission among MSM.

The findings in this report are subject to at least two limitations. First, SCC clients self-selected for HIV and STI testing, and thus might not be representative of the Bangkok MSM community. Second, seeking testing and retesting are likely associated with increased levels of risk, which might artificially bias estimates of HIV and syphilis prevalence and incidence upwards. If this bias is consistent over time, it might not affect 


\section{What is already known on this topic?}

Continuing, increasing, and reemerging epidemics of human immunodeficiency virus (HIV) and other sexually transmitted infections (STIs) have been reported among men who have sex with men (MSM) in the United States and elsewhere in the industrialized world. Limited information is available about the prevalence and incidence of HIV and STI infection among MSM in lower-income and lower-middle income countries.

What is added by this report?

Among MSM followed at a sexual health clinic in Bangkok, Thailand, during 2005-2011, the prevalence of HIV infection was $28.3 \%$ and of all stages of syphilis was $9.8 \%$. Among those returning for HIV or syphilis testing before the end of 2011, the incidence of HIV infection was 6.3 per 100 person-years and of syphilis was 3.6 per 100 person-years.

What are the implications for public health practice?

The ongoing epidemics of HIV and syphilis infection in Bangkok MSM underscores the need for innovative and increased efforts to reduce their spread in this population.

the validity of the trend analysis, showing increases in HIV and syphilis prevalence and incidence over time.

The increasing HIV prevalence and incidence in Bangkok MSM are likely the result of unprotected anal intercourse, the predominant route of HIV transmission among MSM. In this situation, combined implementation of evidence-based HIV prevention interventions to reach the MSM population in Bangkok might be able to reduce HIV transmission. This could include increased acceptance of HIV testing and access to ART for earlier treatment and preexposure prophylaxis in combination with motivational programs that reduce unprotected anal intercourse and increase the use of condoms, along with lubricants that do not weaken latex, during anal intercourse.

\section{References}

1. Kilmarx PH, Supawitkul S, Wankrairoj M, et al. Explosive spread and effective control of human immunodeficiency virus in northernmost Thailand: the epidemic in Chiang Rai Province, 1988-99. AIDS 2000;14:2731-40.

2. Van Griensven F, Varangrat A, Wimonsate W, et al. Trends in HIV prevalence, estimated HIV incidence, and risk behavior among men who have sex with men in Bangkok, Thailand, 2003-2007. J Acquir Immune Defic Syndr 2010;53:234-9.

3. Phanuphak N, Pattanachaiwit S, Pankam T, et al. Active voluntary counseling and testing with integrated CD4 count service can enhance early HIV testing and early CD4 count measurement: experiences from the Thai Red Cross anonymous clinic in Bangkok, Thailand. J Acquir Immune Defic Syndr 2011;56:244-52.

4. Ananworanich J, Phanuphak N, Souza M, et al. Incidence and characterization of acute HIV-1 infection in a high-risk Thai population. AIDS 2008;49:151-5.

5. Sungkanuparph S, Techasathit W, Utaipiboon C, et al. Thai national guidelines for antiretroviral therapy in HIV-1 infected adults and adolescents 2010. Asian Biomed 2010;4:515-28.

6. Sullivan PS, Hamouda O, Delpech V, et al. Reemergence of the HIV epidemic among men who have sex with men in North America, Western Europe, and Australia, 1996-2005. Ann Epidemiol 2009;19:423-31.

7. Dombrowski JC, Harrington RD, Golden MR. Evidence for the longterm stability of HIV transmission-associated sexual behavior after HIV diagnosis. Sex Transm Dis 2013;40:41-5.

8. Grant R, Lama JR, Anderson RA, et al. Pre-exposure chemoprophylaxis for HIV prevention in men who have sex with men. N Engl J Med 2010;363:2587-99.

9. Cohen M, Chen YQ, McCauley M, et al. Prevention of HIV-1 infection with early antiretroviral therapy. N Engl J Med 2011;365:493-505. 


\section{Use of 13-Valent Pneumococcal Conjugate Vaccine and 23-Valent Pneumococcal Polysaccharide Vaccine Among Children Aged 6-18 Years with Immunocompromising Conditions: Recommendations of the Advisory Committee on Immunization Practices (ACIP)}

On February 20, 2013, the Advisory Committee on Immunization Practices (ACIP) recommended routine use of 13-valent pneumococcal conjugate vaccine (PCV13; Prevnar 13, Wyeth Pharmaceuticals, Inc., a subsidiary of Pfizer, Inc.) for children aged 6-18 years with immunocompromising conditions, functional or anatomic asplenia, cerebrospinal fluid (CSF) leaks, or cochlear implants who have not previously received PCV13. PCV13 should be administered to these children regardless of whether they received the 7-valent pneumococcal conjugate vaccine (PCV7) or the 23-valent pneumococcal polysaccharide vaccine (PPSV23). Recommendations for PPSV23 use for children in this age group remain unchanged. The evidence for the benefits and risks associated with PCV13 vaccination of children with immunocompromising conditions was evaluated using the Grading of Recommendations, Assessment, Development, and Evaluation (GRADE) framework (1). This recommendation reflects a policy change from permissive and off-label recommendation of PCV13 in the pediatric immunocompromised population to a category $\mathrm{A}$ recommendation $(1,2)$. This report summarizes the evidence considered by ACIP to make this recommendation and reviews the recommendations for use of PCV13 and PPSV23 for children aged 6-18 years.

Recommendations for routine use of vaccines in children, adolescents and adults are developed by the Advisory Committee on Immunization Practices (ACIP). ACIP is chartered as a federal advisory committee to provide expert external advice and guidance to the Director of the Centers for Disease Control and Prevention (CDC) on use of vaccines and related agents for the control of vaccine-preventable diseases in the civilian population of the United States. Recommendations for routine use of vaccines in children and adolescents are harmonized to the greatest extent possible with recommendations made by the American Academy of Pediatrics (AAP), the American Academy of Family Physicians $(A A F P)$, and the American College of Obstetrics and Gynecology (ACOG). Recommendations for routine use of vaccines in adults are harmonized with recommendations of AAFP, ACOG, and the American College of Physicians (ACP). ACIP recommendations adopted by the CDC Director become agency guidelines on the date published in the Morbidity and Mortality Weekly Report (MMWR). Additional information regarding ACIP is available at http://www.cdc.gov/vaccines/acip.

\section{Epidemiology of Pneumococcal Infection in Immunocompromised Persons and Current Recommendations}

Streptococcus pneumoniae (pneumococcus) is a leading cause of serious infections, including sepsis and meningitis, and accounts for significant morbidity and mortality in the United States (3). PCV13 was licensed by the Food and Drug Administration (FDA) for prevention of invasive pneumococcal disease (IPD) and otitis media in infants and young children in February 2010 when it replaced the 7-valent conjugate vaccine (PCV7; Prevnar, Wyeth Pharmaceuticals, Inc.) (4). PCV13 is recommended for all children aged 2-59 months and for children aged 60-71 months with chronic medical conditions (e.g., heart disease and diabetes), immunocompromising conditions (e.g., human immunodeficiency virus $[\mathrm{HIV}])$, functional or anatomic asplenia, CSF leaks, or cochlear implants. For children aged 6-18 years with immunocompromising conditions, functional or anatomic asplenia, CSF leaks, or cochlear implants, there has been a permissive and off-label ACIP recommendation (4). Vaccination with PPSV23 also is recommended for children aged 2-18 years with underlying medical conditions after completing all recommended PCV13 doses. Pneumococcal conjugate vaccines have decreased the rates of IPD directly in vaccinated children and indirectly (herd protection) in unvaccinated persons (4). Whereas overall and PCV7-type rates of IPD in HIV-infected adults decreased by $25 \%$ and $88 \%$, respectively, rates of PCV7-type IPD in this population have remained 40 times higher than rates among healthy adults in the same age group 7 years post-PCV7 introduction for children (5). These data demonstrated that immunocompromised adults have benefitted from herd protection but still remain at high risk for disease. In June 2012, after new licensure for PCV13 in adults aged $>50$ years, ACIP recommended routine use of PCV13 in addition to PPSV23 for PCV13-naïve adults aged $\geq 19$ years with immunocompromising conditions, functional or anatomic asplenia, CSF leaks, or cochlear implants (6).

During 2007-2009, the average annual incidence of IPD among children aged $6-18$ years was 2.6 cases per 100,000 , with $57 \%$ of IPD caused by serotypes included in PCV13 (CDC, Active Bacterial Core surveillance 2007-2009, unpublished data, 2013). Among immunocompromised children aged 6-18 
years, $49 \%$ of IPD was caused by serotypes included in PCV13, and an additional 23\% by serotypes included in PPSV23. Incidence rates (cases per 100,000) of PCV13-type IPD among children aged 6-18 years with hematologic malignancies were estimated at 1,282 (rate ratio [RR], compared with children without this condition, of $822 ; 95 \%$ confidence interval $[\mathrm{CI}]=687-983), 197$ for those with HIV infection $(\mathrm{RR}=122$; $\mathrm{CI}=94-161)$, and 56 for those with sickle cell disease (SCD) $(\mathrm{RR}=27 ; \mathrm{CI}=9-73)$ (Figure) (CDC, Active Bacterial Core surveillance 2007-2009, unpublished data, 2013).

\section{PCV13 Efficacy, Immunogenicity, and Safety Among Immunocompromised Persons}

Studies of pneumococcal conjugate vaccines containing similar but fewer antigens have been conducted among persons with immunocompromising conditions. From a randomized controlled trial among HIV-infected children aged 2-45 months in South Africa, the efficacy of a 9-valent pneumococcal conjugate vaccine (PCV9) was estimated as $65 \%(\mathrm{CI}=24 \%-86 \%)$ against IPD and $13 \%(\mathrm{CI}=-7 \%-29 \%)$ against radiologically confirmed pneumonia ( 7$)$. Vaccine efficacy of PCV7 against PCV7-type IPD in HIV-infected adults in Malawi was estimated at 74\% (CI $=30 \%-90 \%)(8)$. An observational study conducted in the United States among children aged $\leq 10$ years with SCD estimated a vaccine effectiveness against IPD to be $81 \%(\mathrm{CI}=19 \%-96 \%)$ among those who received at least 1 dose of PCV7 (9). Although vaccine efficacy and effectiveness have been demonstrated, the duration of protection against IPD remains unknown.

In January 2013, FDA approved PCV13 in healthy children aged 6-17 years for the prevention of IPD caused by serotypes included in the vaccine. In children aged 6-9 years, vaccine effectiveness was inferred from noninferiority of immunoglobulin $\mathrm{G}(\mathrm{IgG})$ antibody responses after a single dose to IgG responses after a fourth PCV13 dose among healthy infants. For children aged 10-17 years, opsonophagocytic assay (OPA) geometric mean titers were compared with corresponding OPA titers achieved by children aged 6-9 years who were enrolled in the same study (FDA, Vaccines and Related Biological Products Advisory Committee, unpublished data, 2013). Among children with SCD aged 6-18 years, 1 dose of PCV13 elicited significant immune responses for all 13 serotypes, as measured by serotype-specific IgG concentrations (10). In a randomized trial, HIV-infected children aged 2-45 months who received 3 doses of PCV9 had significantly higher OPA titers compared with a placebo group (11). Another trial comparing PCV7 to placebo in HIV-infected children aged $<2$ years showed that the vaccinated children had significantly higher serotype-specific IgG titers compared with placebo (12). Data from an observational study evaluating sequential
FIGURE. Annual average incidence of PCV13-type IPD in children aged 6-18 years, with and without selected underlying immunocompromising conditions - United States 2007-2009

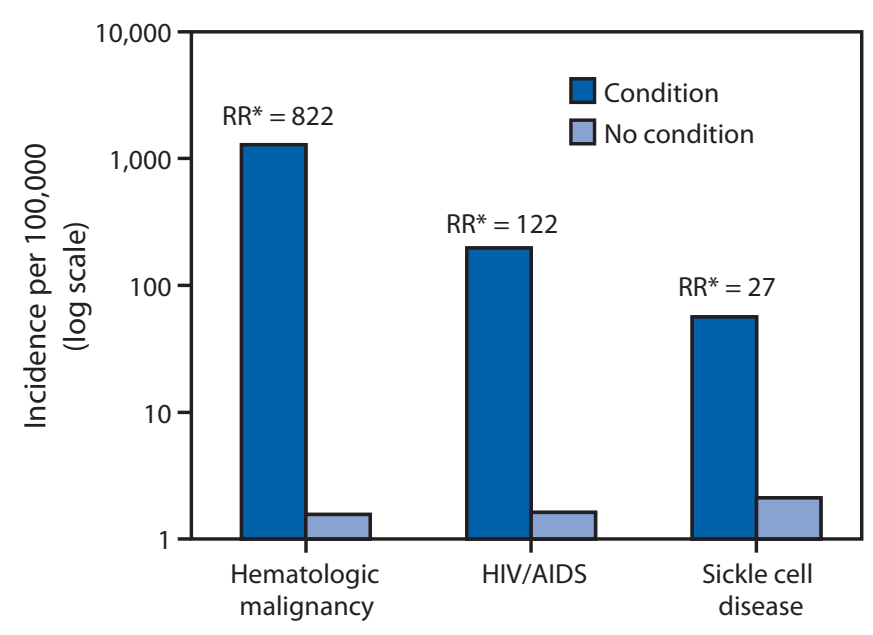

Immunocompromising condition

Abbreviations: PCV13 $=13$-valent pneumococcal conjugate vaccine; $\mathrm{IPD}=$ invasive pneumococcal disease; $\mathrm{RR}=$ rate ratio; HIV/AIDS = human immunodeficiency virus/acquired immunodeficiency syndrome.

* RR is comparing IPD rate in children with condition listed to children without that condition.

administration of 2 doses of PCV7 followed by PPSV23 in HIV-infected children aged 2-18 years showed that antibody concentrations following a single dose of PCV7 were as high or higher than following PPSV23 (13).

Current evidence supports the safety of PCV13 in children with immunocompromising conditions. An open-label, singlearm study of 158 children aged 6-18 years with SCD who previously received PPSV23 showed that 1 dose of PCV13 was safe (10). The most common adverse events reported within 7 days of 1 dose included myalgia (74.8\%), fatigue (66.1\%), and headache (53.6\%); less common events included arthralgia $(39.8 \%)$, fever $(26 \%)$, vomiting $(15.4 \%)$, and diarrhea (13.3\%). Severe adverse events were reported among $8 \%$ of the children and included sickle cell crisis (4\%), acute chest syndrome (2\%), and fever (2\%); no deaths were reported (10). In a PCV7 efficacy trial among HIV-infected children, the most common adverse events were severe induration, erythema, fever, and restricted leg movement; no serious adverse events were reported and no significant differences were observed in the number of adverse events between the vaccinated and unvaccinated group (12).

\section{PPSV23 in Immunocompromised Children}

PPSV23 contains 12 of the serotypes included in PCV13, plus 11 additional serotypes, which account for $23 \%$ of IPD among immunocompromised children aged 6-18 years (CDC, Active Bacterial Core surveillance 2007-2009, unpublished 
data, 2013). PPSV23 currently is recommended for children aged $\geq 2$ years with increased risk for IPD (4). Given the high burden of IPD caused by serotypes in PPSV23 but not in PCV13, broader protection might be provided through use of both PCV13 and PPSV23. There are no changes to the existing PPSV23 recommendations (4).

\section{ACIP Recommendations for PCV13 and PPSV23 Use in Immunocompromised Children Aged 6-18 Years}

PPSV23-naïve children. ACIP recommends that children aged 6-18 years who have not received PCV13 and are at increased risk for IPD because of anatomic or functional asplenia (including SCD), HIV infection, cochlear implant, CSF leak, or other immunocompromising conditions receive a single PCV13 dose first, followed $\geq 8$ weeks later by a dose of PPSV23. A second PPSV23 dose is recommended 5 years after the first PPSV23 dose for children with anatomic or functional asplenia (including SCD), HIV infection, or other immunocompromising conditions (Table).
Previous vaccination with PPSV23. Children aged 6-18 years who have not received PCV13; are at increased risk for IPD because of anatomic or functional asplenia, including SCD, HIV infection, CSF leaks, cochlear implants, or other immunocompromising conditions; and who previously received $\geq 1$ doses of PPSV23 should be given a single PCV13 dose $\geq 8$ weeks after the last PPSV23 dose, even if they have received PCV7. If a second PPSV23 dose is indicated, it should be given $\geq 5$ years after the first PPSV23 dose. These children should not receive more than 2 doses of PPSV23 before age 65 years.

\section{Reported by}

Nancy M. Bennett, MD, Advisory Committee on Immunization Practices Pneumococcal Work Group. Tamara Pilishvili, MPH, Cynthia G. Whitney, MD, Matthew Moore, MD, Ryan Gierke, MPH, Respiratory Diseases Br, Div of Bacterial Diseases, National Center for Immunization and Respiratory Diseases; Aaron M. Harris, MD, EIS Officer, CDC. Corresponding contributor: Tamara Pilishvili,tdp4@cdc.gov.

TABLE. Medical conditions or other indications for administration of PCV13,* and indications for PPSV23 ${ }^{\dagger}$ administration and revaccination for children aged 6-18 years $\$$

\begin{tabular}{|c|c|c|c|c|}
\hline \multirow[b]{2}{*}{ Risk group } & \multirow[b]{2}{*}{ Underlying medical condition } & \multirow{2}{*}{$\begin{array}{c}\text { PCV13 } \\
\text { Recommended }\end{array}$} & \multicolumn{2}{|c|}{ PPSV23 } \\
\hline & & & Recommended & $\begin{array}{c}\text { Revaccination } 5 \text { yrs } \\
\text { after first dose }\end{array}$ \\
\hline Immunocompetent persons & $\begin{array}{l}\text { Chronic heart disease } \\
\text { Chronic lung disease }^{* *} \\
\text { Diabetes mellitus } \\
\text { Cerebrospinal fluid leaks } \\
\text { Cochlear implants } \\
\text { Alcoholism } \\
\text { Chronic liver disease } \\
\text { Cigarette smoking }\end{array}$ & $\checkmark$ & $\begin{array}{l}\checkmark \\
\checkmark \\
\checkmark \\
\checkmark \\
\checkmark \\
\checkmark \\
\checkmark \\
\checkmark\end{array}$ & \\
\hline $\begin{array}{l}\text { Persons with functional or } \\
\text { anatomic asplenia }\end{array}$ & $\begin{array}{l}\text { Sickle cell disease/other hemaglobinopathies } \\
\text { Congenital or acquired asplenia }\end{array}$ & $\checkmark$ & $\begin{array}{l}\checkmark \\
\checkmark\end{array}$ & $\begin{array}{l}\checkmark \\
\checkmark\end{array}$ \\
\hline Immunocompromised persons & $\begin{array}{l}\text { Congenital or acquired immunodeficiencies }{ }^{\dagger \dagger} \\
\text { Human immunodeficiency virus infection } \\
\text { Chronic renal failure } \\
\text { Nephrotic syndrome } \\
\text { Leukemia } \\
\text { Lymphoma } \\
\text { Hodgkin disease } \\
\text { Generalized malignancy } \\
\text { latrogenic immunosuppression }{ }^{\S \S} \\
\text { Solid organ transplant } \\
\text { Multiple myeloma }\end{array}$ & $\begin{array}{l}\checkmark \\
\checkmark \\
\checkmark \\
\checkmark \\
\checkmark \\
\checkmark \\
\checkmark \\
\checkmark \\
\checkmark \\
\checkmark \\
\checkmark\end{array}$ & $\begin{array}{l}\checkmark \\
\checkmark \\
\checkmark \\
\checkmark \\
\checkmark \\
\checkmark \\
\checkmark \\
\checkmark \\
\checkmark \\
\checkmark \\
\checkmark\end{array}$ & $\begin{array}{l}\checkmark \\
\checkmark \\
\checkmark \\
\checkmark \\
\checkmark \\
\checkmark \\
\checkmark \\
\checkmark \\
\checkmark \\
\checkmark \\
\checkmark\end{array}$ \\
\hline
\end{tabular}

\footnotetext{
* 13-valent pneumococcal conjugate vaccine.

† 23-valent pneumococcal polysaccharide vaccine.

$\S$ Children aged 2-5 years with chronic conditions (e.g., heart disease or diabetes), immunocompromising conditions (e.g., human immunodeficiency virus), functional or anatomic asplenia (including sickle cell disease), cerebrospinal fluid leaks, or cochlear implants, and who have not previously received PCV13, have been recommended to receive PCV13 since 2010.

१ Including congestive heart failure and cardiomyopathies.

** Including chronic obstructive pulmonary disease, emphysema, and asthma.

${ }^{+\dagger}$ Includes B-(humoral) or T-lymphocyte deficiency, complement deficiencies (particularly C1, C2, C3, and C4 deficiencies), and phagocytic disorders (excluding chronic granulomatous disease).

$\S \S$ Diseases requiring treatment with immunosuppressive drugs, including long-term systemic corticosteroids and radiation therapy.
} 


\section{Acknowledgments}

Members of the Advisory Committee on Immunization Practices.* Jessica King, MPH, Div of Cancer Prevention and Control, National Center for Chronic Disease Prevention and Health Promotion; Mi Chen, MS, HIV Incidence and Case Surveillance Br, Div of HIV/ AIDS Prevention, National Center for HIV/AIDS, Viral Hepatitis, STD, and TB Prevention; Ruth Link-Gelles, MPH, Amanda Payne, MPH, Respiratory Diseases Br, Div of Bacterial Diseases, National Center for Immunization and Respiratory Diseases.

* Member roster for July 2012-June 2013 available at http://www.cdc.gov/
vaccines/acip/committee/members-archive/members-07-2012-06-2013.html.

\section{References}

1. CDC. GRADE evidence tables—recommendations in MMWR. Atlanta, GA: US Department of Health and Human Services, CDC; 2013. Available at http://www.cdc.gov/vaccines/acip/recs/grade/table-refs.html.

2. Ahmed F, Temte JL, Campos-Outcalt D, Schunemann HJ; ACIP Evidence Based Recommendations Work Group. Methods for developing evidence-based recommendations by the Advisory Committee on Immunization Practices (ACIP) of the U.S. Centers for Disease Control and Prevention (CDC). Vaccine 2011;29:9171-6.

3. Huang SS, Johnson KM, Ray GT, et al. Healthcare utilization and cost of pneumococcal disease in the United States. Vaccine 2011;29:3398-412.

4. CDC. Prevention of pneumococcal disease among infants and children-use of 13-valent pneumococcal conjugate vaccine and 23-valent pneumococcal polysaccharide vaccine: recommendations of the Advisory Committee on Immunization Practices (ACIP). MMWR 2010;59(No. RR-11).

5. Cohen AL, Harrison LH, Farley MM, et al. Prevention of invasive pneumococcal disease among HIV-infected adults in the era of childhood pneumococcal immunization. AIDS 2010;24:2253-62.
6. CDC. Use of 13-valent pneumococcal conjugate vaccine and 23-valent pneumococcal polysaccharide vaccine for adults with immunocompromising conditions: recommendations of the Advisory Committee on Immunization Practices (ACIP). MMWR 2012;61:816-9.

7. Klugman KP, Madhi SA, Huebner RE, Kohberger R, Mbelle N, Pierce N. A trial of a 9-valent pneumococcal conjugate vaccine in children with and those without HIV infection. N Engl J Med 2003;349:1341-8.

8. French N, Gordon SB, Mwalukomo T, et al. A trial of a 7-valent pneumococcal conjugate vaccine in $\mathrm{HIV}$-infected adults. N Engl J Med 2010;362:812-22.

9. Adamkiewicz TV, Silk BJ, Howgate J, et al. Effectiveness of the 7-valent pneumococcal conjugate vaccine in children with sickle cell disease in the first decade of life. Pediatrics 2008;121:562-9.

10. Montalembert M, Abboud MR, Fiquet A, et al. A 2-dose schedule of 13-valent pneumococcal conjugate vaccine (PCV13) given to children with sickle cell disease previously immunized with 23 -valent pneumococcal polysaccharide vaccine (PPSV23): results of a phase 3 study. Presented at the 54th Annual Meeting of the American Society of Hematology, Atlanta, GA; December 8-11, 2012.

11. Madhi SA, Kuwanda L, Cutland C, Holm A, Kayhty H, Klugman KP. Quantitative and qualitative antibody response to pneumococcal conjugate vaccine among African human immunodeficiency virusinfected and uninfected children. Pediatr Infect Dis J 2005;24:410-6.

12. Nachman S, Kim S, King J, et al. Safety and immunogenicity of a heptavalent pneumococcal conjugate vaccine in infants with human immunodeficiency virus type 1 infection. Pediatrics 2003;112(1 Pt 1):66-73.

13. Abzug MJ, Pelton SI, Song LY, et al. Immunogenicity, safety, and predictors of response after a pneumococcal conjugate and pneumococcal polysaccharide vaccine series in human immunodeficiency virus-infected children receiving highly active antiretroviral therapy. Pediatr Infect Dis J 2006;25:920-9. 


\section{Occupationally Acquired Salmonella I 4,12:i:1,2 Infection in a Phlebotomist - Minnesota, January 2013}

On January 25, 2013, the Minnesota Department of Health (MDH) was notified of two clinical cases of Salmonella I 4,12:i:1,2 infection with isolates that had indistinguishable pulsed-field gel electrophoresis (PFGE) patterns. Illness onset dates were January 3 and January 9, 2013. Patients $A$ and $B$ were hospitalized at the same hospital during January 12-15 for dehydration. Investigations indicated that these cases were part of a multistate outbreak associated with frozen mice purchased to feed snakes.

On January 25, the MDH Public Health Laboratory isolated Salmonella I 4,12:i:1,2 with an indistinguishable PFGE pattern from a third Minnesota resident, patient C. Patient $\mathrm{C}$ denied contact with frozen feeder mice or snakes, but was employed as a phlebotomist at the hospital where the two infected patients were hospitalized. Protocol at the hospital requires that each phlebotomist use a hand-held sample tracking device to scan the identification band of each patient from whom blood is drawn. Accessing these records, the infection prevention specialist at the hospital found that patient $\mathrm{C}$ drew blood from patient $\mathrm{A}$ on January 13 and from patients $\mathrm{A}$ and $\mathrm{B}$ on January 14, which was 3 days before onset of patient C's symptoms on January 17. Patient $\mathrm{C}$ reported use of gloves while drawing blood.

In the absence of specific evidence for any other risk factor for Salmonella I 4,12:i:1,2 infection and considering the temporal relationship between exposure and symptom onset, occupational person-to-person contact with patients A or B likely was the source of patient C's infection. Salmonella transmission from infected patients to health-care workers, although rare, has been reported (1). This investigation documents the first reported case of occupationally acquired Salmonella infection in a phlebotomist and underscores the personal risk that health-care workers face when caring for patients. Health-care workers from all disciplines must remain vigilant in protecting themselves from occupationally acquired infections through the use of proven strategies (e.g., regular disinfection of patient-care equipment, hand hygiene, and correct use of personal protective equipment) (2).

\section{Reported by}

Kirk E. Smith, DVM, PhD, Richard Danila, PhD, Joni Scheftel, DVM, Heather Fowler, VMD, Amy Westbrook, MPH, Ginette Dobbins, Minnesota Dept of Health. Mary J. Choi, MD, EIS Officer, CDC. Corresponding contributor: Mary J. Choi, mjchoi@cdc.gov,651-201-5193.

\section{References}

1. Standaert S, Hutchesen R, Schaffner W. Nosocomial transmission of Salmonella gastroenteritis to laundry workers in a nursing home. Infect Control Hosp Epidemiol 1994;15:22-6.

2. CDC. Guidelines for environmental infection control in health-care facilities: recommendations from CDC and the Healthcare Infection Control Practices Advisory Committee (HICPAC). Atlanta, GA: US Department of Health and Human Services, CDC; 2003. Available at http://www.cdc.gov/hicpac/pdf/guidelines/eic_in_hcf_03.pdf. 


\section{Disability and Health Data System Updated}

CDC has updated its Disability and Health Data System (DHDS), a web-based data tool providing state-level data on the health of adults with disabilities. Users can now view data in state profiles, in addition to maps and data tables. State profiles allow users to view several pieces of health information simultaneously by topic area for their state. Additionally, 2011 Behavioral Risk Factor Surveillance System (BRFSS) data have been added to DHDS and are included in maps, data tables, and state profiles. New analyses were added for the 2011 data: health indicators stratified by age, sex, and race/ethnicity, and p-values for health disparities. Indicator labels also were revised to make it easier to interpret the information being viewed.

DHDS is intended to raise awareness of health disparities experienced by adults with disabilities and to inform program and policy initiatives aimed at improving the health of adults with disabilities. Recent data on the health of adults with disabilities in specific states and health program areas are available through DHDS at http://dhds.cdc.gov. Questions about the system can be sent to dhds@cdc.gov.

\section{New Resources on Transplantation Safety}

The U.S. Department of Health and Human Services has released the 2013 PHS Guideline for Reducing Human Immunodeficiency Virus, Hepatitis B Virus, and Hepatitis $C$ Virus Transmission Through Organ Transplantation (1), available online at http://www.publichealthreports.org/issueopen.cfm?articleID $=2975$. This guideline updates the 1994 U.S. Public Health Service (PHS) Guidelines for Preventing Transmission of Human Immunodeficiency Virus Through Transplantation of Human Tissue and Organs (2).

Major changes from the 1994 PHS guidelines are that the 2013 PHS guideline includes 1) recommendations that organ donors be screened for hepatitis B virus (HBV) and hepatitis $\mathrm{C}$ virus (HCV) in addition to human immunodeficiency virus (HIV); 2) recommendations for new, more sensitive laboratory testing; and 3) inclusion of a revised set of risk factors for HIV, HBV, and HCV infection. CDC's Solid Organ Transplantation and the Probability of Transmitting HIV, $H B V$, or HCV: A Systematic Review to Support an Evidence-Based Guideline (3) comprises the primary evidence underlying the recommendations in the 2013 PHS guideline.

In addition, $\mathrm{CDC}$ recently launched a website devoted to transplant safety, which features 1) the role of CDC and other agencies and organizations involved in organ and tissue safety; 2) donor screening and testing requirements; and 3) information for health-care providers. The website can be accessed at http://www.cdc.gov/transplantsafety.

\section{References}

1. Seem DL, Lee I, Umscheid CA, Kuehnert MJ. PHS guideline for reducing human immunodeficiency virus, hepatitis $B$ virus, and hepatitis $C$ virus transmission through organ transplantation. Public Health Rep 2013; 128:247-343.

2. CDC. Guidelines for preventing transmission of human immunodeficiency virus through transplantation of human tissue and organs. MMWR 1994;43(No. RR-8).

3. CDC. Solid organ transplantation and the probability of transmitting HIV, HBV, or HCV: a systematic review to support an evidence-based guideline. Atlanta, GA: US Department of Health and Human Services, CDC; 2013. Available at http://stacks.cdc.gov/view/cdc/12164/. 


\section{Percentage of Uninsured Persons Aged $<65$ Years with No Health Insurance Coverage Because of Cost, ${ }^{*}$ by Race/Ethnicity ${ }^{\dagger}$ - National Health Interview Survey, United States, 2001 and $2011^{\S}$}

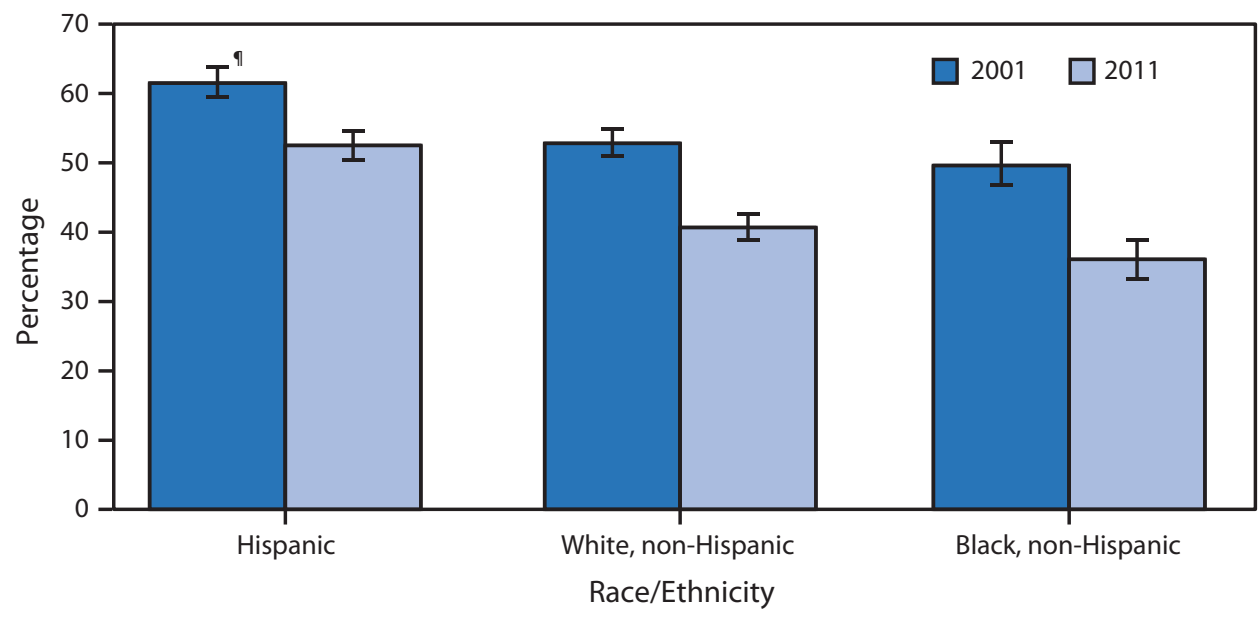

\footnotetext{
* Based on the family respondent's response to a survey question that asked about uninsured family members, "Which of these are reasons [person] stopped being covered or does not have health insurance?" Reasons included lost job or change in employment, change in marital status or death of a parent, ineligible because of age or left school, employer didn't offer or insurance company refused, cost, Medicaid stopped, and other reason. More than one reason could be provided.

† Persons of Hispanic ethnicity might be of any race or combination of races.

$\S$ Estimates are based on household interviews of a sample of the civilian noninstitutionalized U.S. population and are derived from the National Health Interview Survey Family Core component.

I $95 \%$ confidence interval.
}

From 2001 to 2011, the percentage of uninsured persons aged $<65$ years for whom cost was a reason for not having health insurance coverage decreased among uninsured Hispanic, non-Hispanic white, and non-Hispanic black persons. In 2001 and 2011, uninsured Hispanic persons aged $<65$ years were more likely than uninsured non-Hispanic white and non-Hispanic black persons to lack health insurance coverage because of cost.

Sources: Barnes PM, Adams PF, Schiller JS. Summary health statistics for the U.S. population: National Health Interview Survey, 2001. Vital Health Stat 2003;10(217). Available at http://www.cdc.gov/nchs/data/series/sr_10/sr10_217.pdf.

Adams PF, Kirzinger WK, Martinez ME. Summary health statistics for the U.S. population: National Health Interview Survey, 2011. Vital Health Stat 2012;10(255). Available at http://www.cdc.gov/nchs/data/series/sr_10/sr10_255.pdf.

Reported by: Patricia F. Adams, pfa1@cdc.gov, 301-458-4063; Michael E. Martinez, MPH, MHSA. 
The Morbidity and Mortality Weekly Report (MMWR) Series is prepared by the Centers for Disease Control and Prevention (CDC) and is available free of charge in electronic format. To receive an electronic copy each week, visit $M M W R$ 's free subscription page at http://www.cdc.gov/mmwr/mmwrsubscribe. $\mathrm{html}$. Paper copy subscriptions are available through the Superintendent of Documents, U.S. Government Printing Office, Washington, DC 20402; telephone 202-512-1800.

Data presented by the Notifiable Disease Data Team and 122 Cities Mortality Data Team in the weekly MMWR are provisional, based on weekly reports to CDC by state health departments. Address all inquiries about the MMWR Series, including material to be considered for publication, to Editor, MMWR Series, Mailstop E-90, CDC, 1600 Clifton Rd., N.E., Atlanta, GA 30333 or to mmwrq@cdc.gov.

All material in the MMWR Series is in the public domain and may be used and reprinted without permission; citation as to source, however, is appreciated. Use of trade names and commercial sources is for identification only and does not imply endorsement by the U.S. Department of Health and Human Services.

References to non-CDC sites on the Internet are provided as a service to $M M W R$ readers and do not constitute or imply endorsement of these organizations or their programs by CDC or the U.S. Department of Health and Human Services. CDC is not responsible for the content of these sites. URL addresses listed in $M M W R$ were current as of the date of publication.

U.S. Government Printing Office: 2013-623-030/01012 Region IV ISSN: 0149-2195 